\title{
Analysis of Medium-term and Long-term Plans of Developing Social Services Focusing on the Elderly
}

\section{A. Kajanova (Alena Kajanova), S. Ondrasek (Stanislav Ondrasek)}

University of South Bohemia in Ceske Budejovice, Faculty of Health and Social Sciences, ISSPS, Czech Republic.

\section{E-mail address:}

kajanova@zsf.jcu.cz

\section{Reprint address:}

\author{
Alena Kajanova \\ University of South Bohemia in Ceske Budejovice \\ Faculty of Health and Social Sciences, ISSPS \\ J. Boreckeho 1167/27 \\ 37011 Ceske Budejovice \\ Czech Republic
}

Source: Clinical Social Work and Health Intervention

Volume: 11

Issue: 3

Pages: $12-19$

Cited references: 21

\section{Reviewers:}

Gabriela Lezcano

San Francisco, CA, USA

Mageswaari Rajoo

Bangkok, Thailand

\section{Keywords:}

Quality of Life. Older People.

\section{Publisher:}

International Society of Applied Preventive Medicine i-gap

CSWHI 2020; 11(3): 12 - 19; DOI: 10.22359/cswhi_11_3_02 (C Clinical Social Work and Health Intervention

\section{Abstract:}

The aim of the article is to analyze medium-term and long-term development plans of social services with a focus on the elderly population.. For the research was used the document analysis method. These were freely accessible documents, specifically medium-term and long-term development plans of social services in all regions of the Czech Republic. The results of the data analysis were separated into several sections - accommodation services, ambulatory services, field services, and other information about related issues. The results show that the regions, as part of medium-term and long-term development plans of social services for the elderly, focus on quantitative aspects as increasing the capacities of individual accommoda- 
tion facilities which is logical due to the population aging trend. The analysis also shows that the issue of the elderly is understood more as an interdisciplinary issue and the regions focus on prevention, education, as well as on new trends as home care etc.

\section{Introduction}

Currently, population ageing is one of the main issues being addressed by the social policies not only in the Czech Republic but also in Europe. According to Horvathova (2016) persons above the age of 65 make up approximately $8 \%$ of the world-wide population. However, demographic studies suggest that this number will increase to $18 \%$ by 2050 . The increasing number of persons in the post-productive age is also connected to the issue of the number of employed persons decreasing (Pospisil 2014).

The issue of population ageing also influences the social services system. Matousek et al. (2012) characterize social services as a form of assistance that the society offers to the disadvantaged. Social Services can be divided into social support, social care and social prevention (Krejcirova \& Treznerova 2011). These are provided in the form of accommodation, ambulatory, or field forms (Zatloukal 2008). A number of social services is specialized on certain target groups. Social Services primarily targeted at the elderly are according to Act \# 108/2006 Coll. on Social Services: „Daily services centers, day-long or week-long shelters, retirement homes, homes with specific regimes, subsidiary housing, asylum housing, crisis help centers, day-care facilities, over-night facilities, therapy communities, intervention centers and rehabilitation centers."

Community planning is one of the fundamental approaches to creating concepts of social services in each region or city. Community planning is characterized as a methodical approach whose principle is analyzing social conditions, service authorities, social policies, determining objectives and priorities, and creating programs providing services. It also implements appropriate resources and evaluates (Zatloukal 2008). Pilat (2015) states that community planning is one of the most useful development methods and authorities of social services of each region since it investigates the wishes and needs and according to these provides the most ideal way to meet these needs.
The community plan is created by the socalled triad, consisting of social services contractors, providers, and users/clients of social services (Vaskova \& Zezula 2002). Community planning is based in the Act \# 108/2006 Coll. on Social Services. According to this Act, the Ministries and the individual regions are obligated to create medium-term development plans of Social Services both on the regional and state-wide levels. The subsequent cooperation between regions and municipalities is more closely specified in the Regulation \# 387/2017 Coll. which is a regulation changing the Regulation \# 505/2006 Coll. which includes some provisions of the Act on Social Services as subsequently amended, namely in $\$ 39$ which states that the region processes the medium-term development plan of Social Services in cooperation with regional municipalities, representatives of social services, and representatives of persons who the social services are provided to - the representatives of the users. Such a plan serves also a compulsory amendment to applications for subsidies from the state budget.

The article is an output of the project \# LTC18066 Program INTER-EXCELLENCE, INTER-COST subprogram Social Exclusion of the Elderly 65+ Living At Home in the Czech Republic.

\section{Methodology}

For the research, the document analysis method was used. The analyzed data consists of existing current medium-term and long-term development plans of social services in the regions. The analysis includes all regions of the Czech Republic. The objective of the article is to analyze medium-term and long-term development plans of social services in the individual regions of the Czech Republic focusing on the aspect of providing services to the elderly.

\section{Results}

The results of the data analysis were separated into several sections: accommodation servi- 
ces; ambulatory services; field services; other information about related issues. Accommodation and ambulatory services were further analyzed from the quantitative and qualitative perspectives. The results are summarized and graphically shown in the tables below.

\section{Accommodation services}

The first analyzed area are accommodation services for the elderly, see Table 1 . From the quantitative perspective, regions focus on increasing the capacity of current retirement homes, and of other services, as well as on building new retirement homes (Prague, Central Bo- hemian Region, Pardubice Region, Pilsen Region, Olomouc Region). Another objective in this area is transforming accommodation social services for the elderly into accommodations for the elderly suffering from dementia and Alzheimer's, as well as building new homes with specialized regimes (Zlin Region, Pardubice Region, Pilsen Region). From the qualitative perspective, the Zlin Region plans to focus on involving community members in the care for the elderly; the Pilsen Region focuses on education and motivating workers in the social services area; the MoravianSilesian Region focuses on modern trends in elderly care.

Table 1 Analysis of medium-term and long-term development plans of social services accommodation services

\begin{tabular}{|c|c|c|}
\hline \multirow[b]{2}{*}{ Region } & \multicolumn{2}{|l|}{ ACCOMMODATION SERVICES } \\
\hline & Quantitative perspective & Qualitative perspective \\
\hline Prague & $\begin{array}{l}\text { increasing the capacity of social } \\
\text { services and asylum houses }\end{array}$ & \\
\hline $\begin{array}{l}\text { Central Bohemian } \\
\text { Region }\end{array}$ & $\begin{array}{l}\text { increasing the capacity of retirement } \\
\text { homes specializing on dementia and } \\
\text { building new retirement homes }(\mathrm{RH})\end{array}$ & \\
\hline \multicolumn{3}{|l|}{ Vysocina Region } \\
\hline $\begin{array}{l}\text { South Bohemian } \\
\text { Region }\end{array}$ & $\begin{array}{l}\text { supporting the development } \\
\text { of already existing } \mathrm{RH}\end{array}$ & \\
\hline \multicolumn{3}{|l|}{$\begin{array}{l}\text { South Moravia } \\
\text { Region }\end{array}$} \\
\hline Zlín Region & $\begin{array}{l}\text { transforming current capacities } \\
\text { of accommodation services for the } \\
\text { elderly into services for the elderly } \\
\text { with Alzheimer's and other types of } \\
\text { dementia who need continuous care }\end{array}$ & $\begin{array}{l}\text { trying to involve the } \\
\text { community }\end{array}$ \\
\hline $\begin{array}{l}\text { Hradec Kralove } \\
\text { Region }\end{array}$ & $\begin{array}{l}\text { applying for subsidy programs for } \\
\text { accommodation services from the } \\
\text { Ministry of Regional Development } \\
\text { (communal housing for the elderly) }\end{array}$ & \\
\hline Pardubice Region & $\begin{array}{l}\text { increasing the capacity of primarily } \\
\text { relief services; transforming } \\
\text { retirement homes into homes with } \\
\text { specialized regimes }\end{array}$ & \\
\hline $\begin{array}{l}\text { Karlovy Vary } \\
\text { Region }\end{array}$ & transforming year-round services & \\
\hline Pilsen Region & $\begin{array}{l}\text { building retirement homes with } \\
\text { specialized regimes; increasing the } \\
\text { capacity of selected social services }\end{array}$ & $\begin{array}{l}\text { educating and motivating } \\
\text { social services workers }\end{array}$ \\
\hline
\end{tabular}




\begin{tabular}{|l|l|l|}
\hline $\begin{array}{l}\text { Moravia-Silesia } \\
\text { Region }\end{array}$ & $\begin{array}{l}\text { transforming and } \\
\text { implementing modern trends }\end{array}$ \\
\hline Olomouc Region & $\begin{array}{l}\text { building housing for the elderly; } \\
\text { building retirement homes } \\
\text { for the elderly }\end{array}$ & $\begin{array}{l}\text { increasing the transportation } \\
\text { availability of services }\end{array}$ \\
\hline $\begin{array}{l}\text { Usti nad Labem } \\
\text { Region }\end{array}$ & $\begin{array}{l}\text { changing care structure (target } \\
\text { proups); space for dignified } \\
\text { of death) }\end{array}$ & $\begin{array}{l}\text { increasing the availability } \\
\text { of remote services }\end{array}$ \\
\hline Liberec Region & $\begin{array}{l}\text { optimizing networks of } \\
\text { accommodation services; } \\
\text { transforming selected services }\end{array}$ \\
\hline
\end{tabular}

Source: INTER-COST No LTC18066

\section{Ambulatory and field services}

Second area of the services are ambulatory and field services for the elderly, summarized in Table 2. From the quantitative perspective, one of the objectives is increasing the capacity of services, e.g. of home care services (Pardubice Region, Pilsen Region). The Vysočina Region also focuses on home care services - specifically on coverage and stabilization. In this perspective, the regions also focus on extending the field ser- vices, financial and time availability, implementing social services according to different needs and specifics for individual social situations of the elderly, service financing, and engaging volunteers (Zlín Region, Královy Hrady Region, Karlovy Vary Region, Ústí nad Labem Region). From the qualitative perspective, the Central Bohemian Region, Karlovy Vary Region, Pilsen Region, and Ústí nad Labem Region focus primarily on the ambulatory and field services.

Table $\mathbf{2}$ Analysis of medium-term and long-term development plans of social services ambulatory and field services

\begin{tabular}{|c|c|c|}
\hline \multirow[b]{2}{*}{ Region } & \multicolumn{2}{|l|}{ ACCOMMODATION SERVICES } \\
\hline & Quantitative perspective & Qualitative perspective \\
\hline \multicolumn{3}{|l|}{ Prague } \\
\hline $\begin{array}{l}\text { Central Bohemian } \\
\text { Region }\end{array}$ & securing 24-hour care & $\begin{array}{l}\text { focusing on services } \\
\text { for the elderly }\end{array}$ \\
\hline Vysocina Region & $\begin{array}{l}\text { covering and stabilizing home } \\
\text { care services }\end{array}$ & \\
\hline $\begin{array}{l}\text { South Bohemian } \\
\text { Region }\end{array}$ & $\begin{array}{l}\text { supporting the development of } \\
\text { current social services }\end{array}$ & \\
\hline $\begin{array}{l}\text { South Moravia } \\
\text { Region }\end{array}$ & $\begin{array}{l}\text { implementing social services } \\
\text { according to the different needs and } \\
\text { specifics based on the different social } \\
\text { situations of the elderly }\end{array}$ & \\
\hline Zlín Region & $\begin{array}{l}\text { financial and time availability } \\
\text { of services }\end{array}$ & \\
\hline $\begin{array}{l}\text { Hradec Kralove } \\
\text { Region }\end{array}$ & $\begin{array}{l}\text { applying for subsidy programs for } \\
\text { ambulatory and field services from } \\
\text { the Ministry of Regional Development } \\
\text { (communal housing for the elderly) }\end{array}$ & \\
\hline
\end{tabular}




\begin{tabular}{|c|c|c|}
\hline Pardubice Region & increasing the capacity of services & \\
\hline $\begin{array}{l}\text { Karlovy Vary } \\
\text { Region }\end{array}$ & expanding the field services & $\begin{array}{l}\text { preventing possible } \\
\text { consequences of loneliness }\end{array}$ \\
\hline Pilsen Region & $\begin{array}{l}\text { increasing the capacity of home } \\
\text { care services }\end{array}$ & $\begin{array}{l}\text { educating and motivating } \\
\text { social services workers }\end{array}$ \\
\hline \multicolumn{3}{|l|}{$\begin{array}{l}\text { Moravia-Silesia } \\
\text { Region }\end{array}$} \\
\hline \multicolumn{3}{|l|}{ Olomouc Region } \\
\hline $\begin{array}{l}\text { Usti nad Labem } \\
\text { Region }\end{array}$ & $\begin{array}{l}\text { increasing the preferences of field } \\
\text { social services using volunteer work }\end{array}$ & $\begin{array}{l}\text { free transport for } 70+ \\
(\text { sometimes } 65+\text { ) }\end{array}$ \\
\hline Liberec Region & $\begin{array}{l}\text { expanding the opening hours } \\
\text { of field services }\end{array}$ & \\
\hline
\end{tabular}

Source: INTER-COST No LTC18066

\section{Other services and activities}

Table 3, shows other services and activities that regions reflect in their plans. Some of the goals of the individual regions as part of the social services include e.g. education of the elderly; namely focusing on the environmental issues (Prague) or supporting informal education, education at U3As; supporting inter-generational learning (South Moravian Region); developing the Education Institute of the Central Bohemian Region (Central Bohemian Region). Other goals feature prevention programs (primary sickness prevention, crime prevention, anti-drug prevention, transport security prevention, safety of children and the elderly, etc.) (Pardubice Region); or available pub- lic housing (Hradec Kralove Region). Regions also focus on increasing the quality of free time and sports opportunities for the elderly (South Moravian Region, Central Bohemian Region, Liberec Region), supporting the autonomy of the elderly (Zlín Region), as well as a currently very important topic, which is accessible public housing for the elderly (Hradec Kralove Region), and developing at-home and mobile hospice care (South Moravian Region, Karlovy Vary Region). The Liberec and South Moravian Regions plan on focusing on the financial aspects of the elderly, namely on distrains and lowering poverty e.g. the Vysočina Region is also focusing on social services workers and on equalizing their wages.

Table 3 Analysis of medium-term and long-term development plans of social services other services and activities

\begin{tabular}{|c|c|}
\hline & OTHER SERVICES AND ACTIVITIES \\
\hline \multicolumn{2}{|l|}{ Region } \\
\hline Prague & environmental education - ecological behavior of the elderly \\
\hline $\begin{array}{l}\text { Central Bohemian } \\
\text { Region }\end{array}$ & $\begin{array}{l}\text { increasing the quality of free time and sports activities; implementing } \\
\text { and developing the Educational Institute of the Central Bohemian } \\
\text { Region; increasing the quality of life of the elderly }\end{array}$ \\
\hline Vysocina Region & equalizing the wages of social services workers \\
\hline \multicolumn{2}{|l|}{$\begin{array}{l}\text { South Bohemian } \\
\text { Region }\end{array}$} \\
\hline $\begin{array}{l}\text { South Moravia } \\
\text { Region }\end{array}$ & $\begin{array}{l}\text { increasing the quality of all public services; increasing the quality of } \\
\text { health care services and the health of the population; mobile hospices } \\
\text { and palliative care; supporting active ageing; informal education } \\
\text { of the elderly incl. U3As; supporting inter-generational learning }\end{array}$ \\
\hline
\end{tabular}




\begin{tabular}{|l|l|}
\hline Zlín Region & $\begin{array}{l}\text { securing rest for persons taking care of the elderly; supporting the } \\
\text { autonomy of the elderly }\end{array}$ \\
\hline $\begin{array}{l}\text { Hradec Kralove } \\
\text { Region }\end{array}$ & $\begin{array}{l}\text { available public housing for the elderly; increasing the level of } \\
\text { awareness of the elderly who depend on care from others; supporting } \\
\text { inter-resort cooperation (social and health sectors) }\end{array}$ \\
\hline Pardubice Region & $\begin{array}{l}\text { prevention programs (primary sickness prevention, crime prevention, } \\
\text { anti-drug prevention, transport security prevention, safety of children } \\
\text { and the elderly, etc.); creating a system of people interested in } \\
\text { accommodation services for the elderly; mapping out the need for } \\
\text { elderly services who are excluded from social services due to } \\
\text { contraindication }\end{array}$ \\
\hline $\begin{array}{l}\text { Karlovy Vary } \\
\text { Region }\end{array}$ & $\begin{array}{l}\text { interconnecting with home care; developing home care and mobile } \\
\text { hospice care; educating and increasing the quality of professional and } \\
\text { general competences of social services workers }\end{array}$ \\
\hline Pilsen Region & $\begin{array}{l}\text { increasing the level of awareness of the elderly about social services; } \\
\text { investments into social inclusion }\end{array}$ \\
\hline $\begin{array}{l}\text { Moravia-Silesia } \\
\text { Region }\end{array}$ & $\begin{array}{l}\text { trying to gain self-governance over the social services sector; decreasing } \\
\text { the level of poverty of the elderly }\end{array}$ \\
\hline Olomouc Region & $\begin{array}{l}\text { implementing new services for psychiatric patients, interconnecting the } \\
\text { health and social sectors; focusing on communal social services }\end{array}$ \\
\hline $\begin{array}{l}\text { Usti nad Labem } \\
\text { Region }\end{array}$ & focusing on elderly distraints; creating sport opportunities for the \\
\hline siberec Region & ICT skills of the elderly \\
\hline
\end{tabular}

Source: INTER-COST No LTC18066

\section{Discussion}

The analysis shows that one of the priorities from the development perspective of social services for the elderly is building new and increasing the capacity of the current retirement homes. Regions that focus on this issue have relatively large shares of persons over 65 years of age within their population. These regions are Prague with $18.2 \%$, the South Bohemian Region with $16.7 \%$, the Pardubice Region with $18 \%$, the Pilsen Region with $18.4 \%$ (the second largest elderly population, the largest - 19\% - population of the elderly is in the Hradec Kralove Region), and the Olomouc Region with $18.2 \%$ of the elderly (Czech Statistical Office 2015).

The results also show that there is a certain level of transformation of accommodation social services for the elderly. Some regions reflect in their plans the increasing demand for specialized elderly services, primarily accommodation for persons suffering from Alzheimer's and other neurodegenerative illnesses. Currently, the trend in elderly care is the so-called home care. As part of taking care of the elderly, some countries connect home care to communal care. Home care and communal care can be found e.g. in Australia where this type of care is increasingly more popular. According to the Productivity Commission (2008) Home and Community Care (HACC) Program, it serves as support for communal care workers of the program provide basic service and support services for elderly persons or even for younger ones who are part of the program. These services include e.g. health care, housekeeping, social support, as well as lending tools and other necessities (Productivity Commission 2008). There are also other programs that are targeted at specific target groups (veterans, persons with dementia) and based on the time difficulty of the needed care ( 7 or 23 hours) (Productivity Commission 2008). Another country that features home care for the elderly is Sweden (Szebehely 
\& TrydegÅrd 2011). Home care in the Czech Republic could be provided in the natural environment of the clients but unlike the typical home care from other countries, the Czech version according to Act \# 108/2006 on social services does not include providing health care. That is why, according to the analysis, the Karlovy Vary and Ústí nad Labem Regions focus on trying to interconnect the health and social care systems.

Another issue that is currently being widely discussed and supportive is palliative care and its better quality (Hall et al. 2011). A large trend in palliative care in the Czech Republic, as well as world-wide, is at home and field hospice care (WHO, 2011). The forth area that the regional plans focus on and which is also relevant for other countries, e.g. Italy, is the increasing number of persons suffering from Alzheimer's and the specialized care for patients suffering from it which is very resources costly (Varela et al. 2011; Wimo \& Norlund 2007). In the Czech Republic there are very few of such services, a fact that some of the plans also reflect. The last area that is according to the analysis reflected in the plans and discussed abroad is prevention - e.g. countries such as Sweden (Hallberg \& Kristensson 2004), USA, Australia, etc. (Cameron et al. 2018) focus on fall prevention - not only in health care (hospitals) but also as part of social services.

\section{Conclusion}

The results show that the regions, as part of medium-term and long-term development plans of social services for the elderly, focus on quantitative aspects - increasing the capacities of individual accommodation facilities which is logical due to the population ageing trend. A positive finding is that when planning, the question of services for specific target groups is becoming more current such as persons suffering from Alzheimer's or other neurodegenerative illnesses. The analysis also shows that the issue of the elderly is understood more as an interdisciplinary issue and that the regions focus on prevention, as well as education of workers in social services, as well as on new trends such as home care and mobile palliative care.

\section{References:}

1. CAMERON ID, DYER SM, PANAGODA CE, MURRAY GR, HILL KD, CUMMING
RG, KERSE N (2012) Interventions for preventing falls in older people in care facilities and hospitals. Cochrane Database Syst Rev: 12(2). DOI: 10,1002 / 14651858.CD005465. pub3.

2. CSO, SENIOR CITIZENS IN REGIONS (2015) [online]. [Accessed 2019-09-13]. Available under:https://www.czso.cz/csu/ czso/seniori-v-krajich

3. CSO, INTERNATIONAL COMPARISON OF SENIOR CITIZENS (2017) [online]. [Accessed 2019-09-13]. Available under: https://www.czso.cz/csu/czso/seniori-v-cr-vdatech-2017.

4. CSO, COMPARISON OF REGIONS IN THE CZECH REPUBLIC (2018) (income and expenses of regions, municipalities, and voluntary association of municipalities according to regions in 2017); 2019. [online] [Accessed 2019-09-13]. Available under: https:/ /www.czso.cz/csu/czso/6- mistni-rozpoctyglvcf1e6fx.

5. HALL S, KOLLIAKOU A, PETKOVA H, FROGGATT K, HIGGINSON IJ (2011) Interventions for improving palliative care for older people living in nursing care homes. Cochrane Database Sys Rev: 16(3). DOI: 10. 1002/14651858.CD007132.pub2.

6. HALLBERG IR, KRISTENSSON J (2004) Preventive home care of frail older people: a review of recent case management studies. Journal of Clinical Nursing: 13(2): 112-120. DOI: 10.1111/j.1365-2702.2004.01054.x.

7. HORVATHOVAZ (2016) Social systems and policies. Prague: Metropolitan Univ. Prague p. 31 .

8. HROZENSKA M, DVORACKOVA D (2013) Social care of senior citizens. Prague: Grada, $192 \mathrm{p}$.

9. JANECKOVA E, CIBEROVA H, MACH P (2016). Guide through the system of providing social services: solutions of fundamental issues of providing social services, form templates, contractual matters. Olomouc: ANAG, p. 350.

10. KREJCIROVA O, TREZNEROVA I (2011) Small lexicon of social services. Olomouc: Palacky University Olomouc, p. 85.

11. MATOUSEK O, et al. (2012) Fundaments of social work. Prague: Portal p. 312.

12. PILAT M (2015) Communal planning of so- 
cial services in current theory and practice. Prague: Portal, p. 200.

13. POSPISIL D (2014) National development strategy of social sciences for the 2016-2025 period. Prague: MPSV, p. 231.

14. PRODUCTIVITY COMMISSION (2008) Trends in Aged Care Services: some implications, Commission Research Paper. Austrália: Canberra, p. 267.

15. SZEBEHELY M, TRYDEGARD GB (2011) Home care for older people in Sweden: a universal model in transition. Health \& Social Care in the Community: 20(3): 300-309. DOI: $10.1111 / j .1365-2524.2011 .01046 . x$.

16. VARELA G, VARONA L, ANDERSON K, SANSONI J (2011). Alzheimer's care at home: a focus on caregivers strain. Professioni infermieristiche: 64(2), 113. PMCI: PMC3662364.

17. VASKOVA V, ZEZULA O (2002) Community planning - public matter. Prague: MPSV p. 15.
18. VIMO A, NORLUND A (2007). Cost-effectiveness of treatments for Alzheimer's dementia. Expert Review of Pharmacoeconomics \& Outcomes Research: 7(1): 83-90. DOI: 10.1586/14737167.7.1.83

19. WORLD HEALTH ORGANIZATION (2011). Palliative care for older people: better practices. Denmark: Copenhagen p. 72.

20. STATUTE No. 108/2006 Coll., concerning social services. In: Collection of statutes of the Czech Republic; 2006. [online]. [Accessed 2019-08-09]. Available under: https:// www.beck-online.cz/bo/chapterview- document.seam?documentId=onrf6mrqga3f6mjq hawtena.

21. ZATLOUKAL L (2008). Planning development of social services using the community planning method. Olomouc: Palacký University Olomouc p. 249. 